\title{
Changes in Conjunctival Hemodynamics Predict Albuminuria in Sickle Cell Nephropathy
}

\author{
Ali Kord Valeshabad ${ }^{a}$ Justin Wanek ${ }^{a}$ Santosh L. Saraf ${ }^{c}$ Bruce I. Gaynes ${ }^{d}$ \\ Victor R. Gordeuk ${ }^{c}$ Robert E. Molokie ${ }^{b, c, e}$ Mahnaz Shahidi ${ }^{a}$ \\ Departments of a Ophthalmology and Visual Sciences and ${ }^{b}$ Biopharmaceutical Sciences, ${ }^{c}$ Division of Hematology/Oncology, \\ University of Illinois at Chicago, d Department of Ophthalmology, Loyola University Medical Center, e Jesse Brown VA Medical \\ Center, Chicago, III., USA
}

\section{Key Words}

Sickle cell disease $\cdot$ Bulbar conjunctiva $\cdot$ Hemodynamics . Kidney $\cdot$ Albuminuria

\begin{abstract}
Background: Albuminuria is an early manifestation of deterioration in renal function in subjects with sickle cell disease (SCD). Hyperfiltration may be an early mechanism for kidney damage in SCD. The purpose of the current study was to determine the association between conjunctival hemodynamics and albuminuria in SCD subjects with preserved glomerular filtration rate. Methods: Conjunctival microcirculation imaging was performed to measure conjunctival diameter and axial blood velocity (V) in 35 SCD and 10 healthy control subjects. Albuminuria, defined as albumin excretion ratio (AER), was obtained from the medical charts. Based on the $95 \% \mathrm{Cl}$ of conjunctival $V$ in control subjects $(0.40-0.60 \mathrm{~mm} / \mathrm{s}), \mathrm{SCD}$ subjects were allocated to 3 groups: $V 1<0.40 \mathrm{~mm} / \mathrm{s}(\mathrm{n}=7)$, $\mathrm{V} 2$ of $0.40-0.60 \mathrm{~mm} / \mathrm{s}(\mathrm{n}=18)$ and V3 $\geq 0.60 \mathrm{~mm} / \mathrm{s}(\mathrm{n}=10)$. Results: Mean log(AER) measurements in the V1, V2 and V3 groups were $1.08 \pm 0.67,1.39 \pm 0.59$ and $2.00 \pm 0.91 \mathrm{mg} / \mathrm{g}$ creatinine, respectively, and followed a positive linear trend from the V1 to V3 groups ( $p=0.01)$. By multivariate linear regression analysis, conjunctival $V$ significantly correlated with albuminuria ( $p=0.01$ ) independent of age, blood pressure, a-thalassemia, hematocrit, white blood cell count and lac-
\end{abstract}

tate dehydrogenase concentration. Conclusions: Increased conjunctival $\mathrm{V}$ is associated with albuminuria in SCD subjects. Assessment of conjunctival microvascular hemodynamics may improve our understanding of the pathophysiology and clinical management of sickle cell nephropathy.

(c) 2015 S. Karger AG, Basel

\section{Introduction}

Sickle cell disease (SCD) is among the most common monogenetic diseases in the United States and is characterized by the formation of rigid, sickle shaped erythrocytes [1]. Sickle cell nephropathy (SCN) is a well-known cause of morbidity and mortality in SCD subjects [2], with structural and functional abnormalities throughout the nephron $[3,4]$. An early sign of SCN is hyperfiltration, which presents with increased renal blood flow and glomerular filtration rate (GFR). Persistently elevated GFR in SCD subjects can be a precursor of glomerular damage and sclerosis, which may lead to progressive renal insufficiency $[3,5,6]$. While glomerular damage is progressing, there is a switch from hyperfiltration to a normal GFR and then a reduced GFR [7, 8]. Albuminuria is a hallmark of early kidney damage in SCD, and often occurs before the GFR decreases to below the normal range [9].

\section{KARGER 125}

C 2015 S. Karger AG Base

0250-8095/15/0416-0487\$39.50/0

E-Mail karger@karger.com

www.karger.com/ajn
Mahnaz Shahidi, PhD

Department of Ophthalmology and Visual Sciences

University of Illinois at Chicago, 1855 West Taylor Street

Chicago, IL 60612 (USA)

E-Mailmahnshah@uic.edu 
Early detection of renal dysfunction in SCD subjects is problematic, in part due to an inaccurate estimation of GFR in SCD subjects [10], and the presence of albuminuria even in individuals with apparently preserved GFR $[11,12]$. Albuminuria may be associated with a rapid progression to worsening renal dysfunction [13]. Once endstage renal disease is reached, there is a marked increase in the mortality rate of those with SCD [14]. Previous studies have investigated clinical factors associated with proteinuria in SCD, including older age $[9,15]$, increased blood pressure [16], low hemoglobin levels [7], hemolysis [17], leukocytosis [18], absence of $\alpha$-thalassemia [19] and stroke [18]. Nevertheless, these factors do not fully account for all the heterogeneity associated with albuminuria in SCN, and factors associated with proteinuria in the subjects with preserved GFR are not well understood.

SCD is a systemic vascular disease [20]. Events originating elsewhere in SCD subjects can target the kidney, and the kidney, in turn, can engage in long-range signaling to distant organs and tissues [21-23]. Furthermore, microvascular hemodynamics in the conjunctiva have been shown to be sensitive to the systemic severity of disease [24] and are altered in other SCD complications including stroke [25], and sickle cell retinopathy [26]. Although the conjunctival microcirculation has been assessed in SCD subjects [2730], to our knowledge, there are no published data regarding the microvascular hemodynamic properties in relation to kidney function in SCD subjects with preserved GFR. The purpose of the current study was to determine the association between conjunctival hemodynamic properties and albuminuria in SCD subjects with preserved GFR.

\section{Patients and Methods}

\section{Subjects}

This research study was approved by an Institutional Review Board of the University of Illinois at Chicago. Prior to subject enrollment, the research study was explained to the subjects, and informed consents were obtained according to the tenets of the Declaration of Helsinki. Ten healthy African-American control subjects ( 1 man and 9 women) without a history of cerebrovascular, hypertension or ocular diseases and 35 subjects (14 men and 21 women) with a clinical diagnosis of sickle cell anemia (SS 32, $S \beta^{0}$-thalassemia 3) participated in this study. Only SCD subjects with estimated GFR (eGFR) $\geq 60 \mathrm{ml} / \mathrm{min} / 1.73 \mathrm{~m}^{2}$ were included, which corresponds to stages 0,1 and 2 of the Kidney Disease Outcomes Quality Initiative (KDOQI) classification of chronic kidney disease [31]. The exclusion criteria for SCD subjects were a history of blood transfusion within 2 months prior to imaging, $<2$ urine samples to define albuminuria status, diagnosis of diabetes mellitus and dry eye syndrome or use of local sympathomimetic or para-sympatholytic medications prior to conjunctival imaging. The majority of SCD subjects ( $\mathrm{n}=28$ ) who participated in the study were those from our previous published studies [26, 30, 32, 33].

Clinical data including the subject's age, sex, body mass index (BMI) and history of hydroxyurea (HU) treatment were obtained from the clinical charts. Laboratory data including hematocrit (HCT), reticulocyte (Ret), white blood cell (WBC), neutrophil and platelet (PLT) counts and lactate dehydrogenase (LDH) levels within 3 months of imaging were recorded. Fetal hemoglobin ( $\mathrm{HbF})$ data were recorded within 6 months of imaging. Systolic and diastolic blood pressure (SBP and DBP, respectively) were measured either at the time of imaging ( 7 of 35 subjects) or within a few hours of imaging during the subject's clinic visit (28 of 35 subjects). The mean SBP and DBP were then converted to mean arterial blood pressure (MAP) using a standard formula: $\mathrm{MAP}=1 / 3(\mathrm{SBP})+2 / 3(\mathrm{DBP})$. BMI was defined as weight in kilograms divided by the square of the height in meters squared. Alpha thalassemia status was determined by multiplex PCR, as previously described [34], and was available in 24 of 35 SCD subjects.

\section{Definition of Albuminuria}

Clinical markers of renal function were obtained from the inpatient or outpatient clinical charts, and included albumin excretion ratio (AER), serum creatinine ( $\mathrm{Cr}$ ) level and eGFR. The median time interval between the renal test and conjunctival imaging was 4 months (interquartile range $2-6$ months), and in the majority of subjects (30 out of 35), the time interval was within 6 months of imaging. AER category was defined as normoalbuminuria (AER $<30 \mathrm{mg} / \mathrm{g}$ creatinine), microalbuminuria $(\mathrm{AER}=30-300 \mathrm{mg} / \mathrm{g}$ creatinine) or macroalbuminuria (AER $\geq 300 \mathrm{mg} / \mathrm{g}$ creatinine). The presence of microalbuminuria and macroalbuminuria was confirmed in at least 2 consecutive random urine samples. The eGFR was determined from the Chronic Kidney Disease Epidemiology Collaboration (CKD-EPI) equation 1 [35], which is the preferred equation to determine the eGFR in adult SCD subjects [36];

$$
\mathrm{eGFR}=141 \times \min (\mathrm{Cr} / \kappa, 1)^{\alpha} \times \max (\mathrm{Cr} / \kappa, 1)^{-1.209} \times 0.993^{\text {age }} \times
$$$$
1.018 \text { (if female) } \times 1.159 \text { (if African-American) }
$$

where $\mathrm{Cr}$ is serum creatinine $(\mathrm{mg} / \mathrm{dl}), \kappa$ is 0.7 for females and 0.9 for males, $\alpha$ is -0.329 for females and -0.411 for males, min indicates the minimum of $\mathrm{Cr} / \kappa$ or 1 and max indicates the maximum of $\mathrm{Cr} / \kappa$ or 1 . The latter 2 coefficients in the equation (1.018 and 1.159) are considered to be 1 if the subject is not female or not African-American, respectively.

\section{Conjunctival Microcirculation Imaging}

Imaging of the conjunctival microcirculation was performed with our previously described optical imaging system (EyeFlow ${ }^{\mathrm{TM}}$ ) [37]. The imaging system, comprising a slit lamp biomicroscope and a digital charged coupled device camera (Photometrics, Tuscon, Ariz., USA), was used to acquire image sequences of red blood cell movement within the conjunctiva microcirculation at high magnification. An external fixation target was presented to the subjects to minimize eye movement and several 2-s image sequences were acquired. In each image sequence, $\geq 10$ consecutive frames were manually selected for analysis based on image focus and the absence of large eye movements.

Our method for deriving conjunctival hemodynamic properties has been previously described and was validated [26, 30, 3739]. Briefly, image sequences were first registered to correct for eye 
movement, then hemodynamic measures of conjunctival diameter (D) and axial blood velocity (V) were derived for several selected conjunctival venules. To determine conjunctival $\mathrm{D}$, a centerline of a manually selected venule was automatically extracted, and D was calculated as the average full width at half maximum of intensity profiles generated perpendicular to the vessel centerline along the vessel length. Conjunctival $\mathrm{V}$ was assessed by measuring the movement of red blood cells along the vessel centerline in consecutive frames using spatial-temporal images. These images displayed intensity variation along the centerline of the vessel (rows) as a function of time (columns), revealing diagonal bands corresponding to the motion of aggregated red bloods cells (or plasma gaps). Conjunctival $\mathrm{V}$ was derived by determining the slope of the prominent bands [37, 38]. Venules were distinguished from arterioles by visualizing the motion of red blood cells within the vessel and determining whether blood drained into another vessel (venule) or diverged into vessel branches (arteriole). Hemodynamic measurements were obtained in venules because they are more frequent, have less pulsatility $[40,41]$ and have higher contrast compared to arterioles. The individuals who performed conjunctival imaging and image analysis were masked to the renal status of the subjects.

The median number of venules that were analyzed in each subject was 11 venules (interquartile range $7-20$ ). Conjunctival D and axial $\mathrm{V}$ measurements were obtained in a total of 179 and 432 conjunctival venules of 10 control and 35 SCD subjects. Mean conjunctival D and $\mathrm{V}$ were calculated in each subject for further statistical analysis.

\section{Statistical Analysis}

According to the $95 \%$ CI of mean conjunctival V (0.40-0.60 $\mathrm{mm} / \mathrm{s}$ ) in control subjects, SCD subjects were categorized to 1 of 3 V groups: $\mathrm{V} 1,<0.40 \mathrm{~mm} / \mathrm{s} ; \mathrm{V} 2,0.40-0.60$ and $\mathrm{V} 3,>0.60 \mathrm{~mm} / \mathrm{s}$. A one-way analysis of variance, post hoc and contrast analyses were performed to compare differences and linear trends of continuous variables among V groups. Categorical variables were compared using the chi-square test. First, the Pearson correlation coefficient was computed to assess the relationship between albuminuria and continuous variables including conjunctival $\mathrm{D}$ and $\mathrm{V}$ and demographic and clinical data. Then, variables with a $p \leq 0.2$ on univariate analysis (conjunctival V, HCT, WBC and LDH) and traditionally known risk factors (age, MAP and a-globin deletions) were included in the multiple linear regression analysis after testing for collinearity among independent variables. In the case of collinear relationships among independent variables (HCT, WBC, a-globin deletions with $\mathrm{LDH}$ ), only one variable was included in the final multiple linear regression analysis. For correlation and the multiple linear regression analyses, albuminuria was log-transformed to approximate a normal distribution. Continuous variables were shown as means \pm SD or means \pm SEM. Statistical analysis was performed using SPSS, version 22 (SPSS Inc., Chicago, Ill., USA). The post hoc statistical power for the correlation between conjunctival $\mathrm{V}$ and albuminuria was calculated using $G^{*}$ Power, version 3.1 [42]. Statistical significance was accepted at $\mathrm{p}<0.05$ for regression analyses.

\section{Results}

\section{Clinical Correlates and Albuminuria}

The mean \pm SD age of the control $(38 \pm 11$ years, $\mathrm{n}=$ $10)$ and SCD subjects ( $35 \pm 12$ years, $\mathrm{n}=35)$ was similar $(\mathrm{p}=0.5)$. SBP was not significantly different between control (124 $\pm 14 \mathrm{~mm} \mathrm{Hg}, \mathrm{n}=5)$ and SCD subjects (121 \pm 15 ; $\mathrm{p}=0.7)$, while DBP in SCD subjects $(69 \pm 10 \mathrm{~mm} \mathrm{Hg})$ was significantly lower than in control subjects $(78 \pm 5 \mathrm{~mm}$ $\mathrm{Hg} ; \mathrm{p}=0.04)$. Twenty subjects had normoalbuminuria, 10 subjects had microalbuminuria and 5 subjects had macroalbuminuria. AER did not correlate significantly with age, SBP, DBP, BMI, HCT, HbF, Ret, WBC, neutrophil, PLT, serum Cr or eGFR ( $\mathrm{p} \geq 0.1)$.

\section{Microvascular Hemodynamics and Albuminuria}

Table 1 summarizes demographic and clinical data of SCD subjects stratified by conjunctival V. There was not a significant difference in age, sex, SBP, DBP, MAP, BMI, HU treatment, HCT, HbF, Ret, WBC, neutrophil, PLT, $\mathrm{LDH}$, serum Cr or eGFR among V groups $(\mathrm{p} \geq 0.2)$.

Mean \pm SEM AER measurements in the V1, V2 and V3 groups were $30 \pm 17,68 \pm 31$ and $475 \pm 232 \mathrm{mg} / \mathrm{g}$ creatinine, respectively. Mean \pm SD of conjunctival $D$ and $V$ and $\log$ (AER) measurements in $\mathrm{V}$ groups are summarized in table 2. Mean conjunctival D measurements were not significantly different among the $\mathrm{V}$ groups $(\mathrm{p}=0.3)$ while, by definition, the mean conjunctival $\mathrm{V}$ measurements were different $(\mathrm{p}<0.001)$. Mean $\log ($ AER) measurements differed significantly among the $V$ groups and followed a positive linear trend from the V1 to V3 groups $(p=0.01)$. Mean $\log (\mathrm{AER})$ was significantly higher in the V3 group than in the V1 $(\mathrm{p}=0.01)$ and V2 $(\mathrm{p}=0.04)$ groups. Mean $\log$ (AER) were not statistically different between the V1 and $V 2$ groups $(\mathrm{p}=0.3)$.

Figure 1 displays the relationship between albuminuria and conjunctival V in SCD subjects. There was not a significant correlation between conjunctival D and albuminuria $(\mathrm{r}=0.08, \mathrm{p}=0.7)$, while conjunctival $\mathrm{V}$ correlated significantly with albuminuria $(\mathrm{r}=0.47, \mathrm{p}=0.005)$. As summarized in table 3 , in the multiple linear regression analysis conjunctival $\mathrm{V}$ independently correlated with albuminuria $(p=0.01)$, after adjusting for age, MAP, a-globin deletions, HCT, WBC and $\mathrm{LDH}$ values. $\mathrm{LDH}$ correlated independently with albuminuria $(\mathrm{p}=0.04)$.

\section{Discussion}

SCD subjects with preserved eGFR may develop albuminuria $[11,12]$, indicating a deterioration in renal function [10]. There is little information about the microvascular hemodynamic properties in SCD subjects with preserved eGFR. In this study, we found that SCD subjects with preserved eGFR and higher than normal conjuncti- 
Table 1. Demographic and clinical data of sickle cell subjects, stratified by the conjunctival V to V1 $(<0.40 \mathrm{~mm} / \mathrm{s})$, V2 $(0.40-0.60 \mathrm{~mm} / \mathrm{s})$ and V3 $(\geq 0.60 \mathrm{~mm} / \mathrm{s})$

\begin{tabular}{|c|c|c|c|c|}
\hline Variable & $\mathrm{V} 1(\mathrm{n}=7)$ & $\mathrm{V} 2(\mathrm{n}=18)$ & V3 $(n=10)$ & $\mathrm{p}$ value \\
\hline Age, years & $37 \pm 14$ & $36 \pm 13$ & $32 \pm 10$ & 0.7 \\
\hline Male gender & $3(43)$ & $6(33)$ & $5(50)$ & 0.7 \\
\hline $\mathrm{SBP}, \mathrm{mm} \mathrm{Hg}$ & $111 \pm 14$ & $123 \pm 15$ & $124 \pm 15$ & 0.2 \\
\hline $\mathrm{DBP}, \mathrm{mm} \mathrm{Hg}$ & $65 \pm 9$ & $70 \pm 11$ & $70 \pm 7$ & 0.4 \\
\hline MAP, mm Hg & $80 \pm 10$ & $88 \pm 11$ & $88 \pm 8$ & 0.2 \\
\hline $\mathrm{BMI}, \mathrm{kg} / \mathrm{m}^{2}$ & $26.1 \pm 6.8$ & $25.1 \pm 5.1$ & $26.0 \pm 4.2$ & 0.9 \\
\hline Hydroxyurea & $4(57)$ & $12(67)$ & $6(60)$ & 0.9 \\
\hline Hematocrit & $26.2 \pm 2.4$ & $27.3 \pm 3.7$ & $26.1 \pm 3.3$ & 0.6 \\
\hline $\mathrm{HbF}$ & $7.1 \pm 2.0$ & $8.3 \pm 5.2$ & $6.7 \pm 5.4$ & 0.7 \\
\hline Reticulocyte & $12.0 \pm 11$ & $13.4 \pm 5.5$ & $13.0 \pm 5.3$ & 0.9 \\
\hline WBC count, $10^{9} / 1$ & $10.8 \pm 6.3$ & $9.3 \pm 2.4$ & $10.2 \pm 4.2$ & 0.7 \\
\hline Neutrophil count, $10^{9} / 1$ & $6.0 \pm 4.0$ & $5.0 \pm 2.5$ & $6.0 \pm 3.8$ & 0.6 \\
\hline Platelet count, $10^{9} / 1$ & $462 \pm 194$ & $417 \pm 183$ & $485 \pm 148$ & 0.6 \\
\hline $\mathrm{LDH}, \mathrm{U} / \mathrm{l}$ & $338 \pm 123$ & $350 \pm 137$ & $374 \pm 140$ & 0.8 \\
\hline Serum Cr, mg/dl & $0.85 \pm 0.36$ & $0.72 \pm 0.16$ & $0.80 \pm 0.35$ & 0.5 \\
\hline $\mathrm{eGFR}, \mathrm{ml} / \mathrm{min} / 1.73 \mathrm{~m}^{2}$ & $121 \pm 60$ & $130 \pm 25$ & $128 \pm 31$ & 0.9 \\
\hline
\end{tabular}

Data are reported as mean $\pm \mathrm{SD}$ or number (percentage). $\mathrm{HbF}$ data were not available in 2, 3 and 1 subjects in V1, $\mathrm{V} 2$ and V3 groups, respectively.

Table 2. Mean \pm SD of conjunctival $\mathrm{D}$ and $\mathrm{V}$, and albuminuria measurements, stratified by the conjunctival $\mathrm{V}$ to $\mathrm{V} 1(<0.40 \mathrm{~mm} / \mathrm{s}), \mathrm{V} 2(0.40-0.60 \mathrm{~mm} / \mathrm{s})$ and V3 $(\geq 0.60 \mathrm{~mm} / \mathrm{s})$

\begin{tabular}{lllcc}
\hline Variable & V1 $(\mathrm{n}=7)$ & $\mathrm{V} 2(\mathrm{n}=18)$ & $\mathrm{V} 3(\mathrm{n}=10)$ & $\mathrm{p}$ value \\
\hline Conjunctival D, $\mu \mathrm{m}$ & $16.4 \pm 1.4$ & $16.3 \pm 3.4$ & $18.2 \pm 3.3$ & 0.3 \\
Conjunctival V, mm/s & $0.30 \pm 0.04$ & $0.47 \pm 0.05$ & $0.67 \pm 0.06$ & $<0.001$ \\
$\log ($ AER $), \mathrm{mg} / \mathrm{g}$ creatinine & $1.08 \pm 0.67$ & $1.39 \pm 0.59$ & $2.00 \pm 0.91$ & 0.01 \\
\hline
\end{tabular}

Data are reported as mean $\pm \mathrm{SD}$.

val $\mathrm{V}$ had a greater degree of albuminuria as compared with subjects with preserved eGFR and normal or lower than normal conjunctival V. Furthermore, conjunctival $\mathrm{V}$ independently correlated with albuminuria in SCD subjects with preserved eGFR.

The exact mechanism responsible for the correlation between conjunctival V and albuminuria in SCD subjects with preserved GFR is unclear, although a previously described 'perfusion paradox' in SCD subjects may in part account for these findings [21-23]. In general, the perfusion paradox in SCD is characterized by contrasting perfusion profiles in the local and systemic circulations: hypoperfusion in the local microcirculatory beds occluded by $\mathrm{HbS}$-containing erythrocytes but hyperperfusion in the systemic circulation and a number of regional vasculatures [23]. The perfusion paradox is also believed to happen in SCN [21-23]. Preserved GFR in subjects in this study might be a sign of cortical hyperperfusion, which was likely a manifestation of systemic hyperperfusion [22]. This presumed systemic hyperperfusion may in part account for increased microvascular conjunctival $\mathrm{V}$, as seen in our subjects. The systemic hyperperfusion in SCD subjects without major organ complication has been attributed to higher plasma volume and cardiac output [43, 44] and diminished systemic vascular resistance [43, 45], indicating increased blood $\mathrm{V}$ as documented in organs other than the conjunctiva including the forearm [46], pedal cutaneous area [47] and kidney [48]. Moreover, since cardiac output is higher than normal in SCD subjects due to anemia, the decreased DBP in SCD subjects compared to control subjects is also consistent with presumed reduced systemic vascular resistance, and thereby systemic hyperperfusion. Future studies are needed to directly investigate the association between cardiac output, systemic vascular resistance and conjunctival hemodynamics in SCD subjects. 
Table 3. Unstandardized (B) and standardized (Beta) coefficients of multiple linear regression analysis

\begin{tabular}{lccrl}
\hline $\begin{array}{l}\text { Independent } \\
\text { variables }\end{array}$ & B & $\begin{array}{l}95 \% \\
\text { CI for B }\end{array}$ & Beta & $\begin{array}{l}\mathrm{p} \\
\text { value }\end{array}$ \\
\hline Conjunctival V, mm/s & 2.59 & 0.56 to 4.62 & 0.46 & 0.01 \\
Age, years & 0.001 & -0.02 to 0.02 & 0.01 & 0.9 \\
MAP, mm Hg & -0.15 & -0.04 to -0.01 & -0.20 & 0.3 \\
LDH, U/l & 0.002 & 0.001 to 0.004 & 0.39 & 0.04 \\
\hline
\end{tabular}

Albuminuria is the dependent variable, defined as log-transformed values of AER.

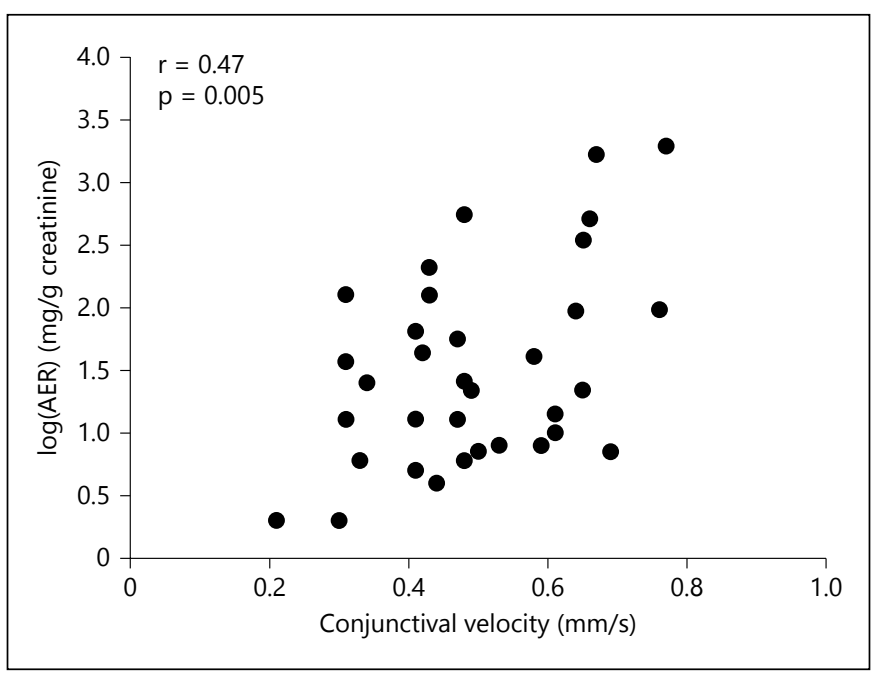

Fig. 1. There was a significant correlation between conjunctival V and albuminuria $(\mathrm{p}=0.005)$. Albuminuria has been shown as logtransformed values of AER. The statistical power was calculated to be 0.85 at a significance level of 0.05 for correlation between conjunctival $\mathrm{V}$ and albuminuria.

In this study, conjunctival $\mathrm{V}$ was associated with albuminuria in SCN, independent of previously reported factors associated with renal function including age $[9,15]$, blood pressure [16], $\alpha$-globin microdeletions [19], HCT [7], hemolysis [17, 49] and leukocytosis [18]. There are multiple pathways for damage to the nephron in SCD including hyperfiltration, hypertension, ischemia from vaso-occlusion, hemolysis-related vasculopathy and chronic cell-free hemoglobin exposure [22]. Albuminuria reflects damage to the glomerulus and may be an early marker of kidney disease and may precede a decline in the eGFR. Our finding of an increased conjunctival V correlating with the degree of albuminuria is consistent with the model of a high flow state, such as hyperfiltration, contributing to earlier stages of glomerular damage and SCN.
Although some SCD subjects with low and normal conjunctival $\mathrm{V}$ had microalbuminuria, increased conjunctival V measurements tended to be found in subjects with macroalbuminuria. Measuring the conjunctival V may allow clinicians to develop a more intensive personalized management strategy including an emphasis on preventative care. Future longitudinal studies with a larger population are needed to determine the predictive value of increased conjunctival $\mathrm{V}$ for development of albuminuria.

The retrospective nature and small sample size were limitations of the current study. Using conjunctival V and albuminuria measurements and the number of subjects in the present study, the statistical power was calculated to be 0.85 at a significance level of 0.05 , indicating sufficient sample size to detect correlation between 2 variables. The clinical renal function tests were performed close to the conjunctival imaging (median time 4 months), thus reducing the potential for variations in renal function markers between the time of imaging and data collection. Conjunctival V measurements in normal subjects in the present study were lower than what has been reported in a previous study [50], which may be attributed to AfricanAmerican origin and larger age range of the control subjects, and to different measurement techniques. Random urine samples were used to define albuminuria which may be a limitation, although determination of albuminuria status was confirmed on 2 consecutive urine samples. Though most available methods are limited for determination of GFR in SCD subjects $[51,52]$, we used the CKDEPI equation [35], which is particularly accurate for the estimation of high GFR values, including glomerular hyperfiltration in SCD subjects [36].

In summary, increased conjunctival $\mathrm{V}$ is associated with albuminuria in sickle cell subjects. Assessment of conjunctival microvascular hemodynamics may help improve our understanding of the pathophysiology and clinical management of SCN.

\section{Acknowledgments}

Supported by NIH grants EY001792, a Senior Scientific Investigator award (M.S.) and an unrestricted departmental grant from Research to Prevent Blindness.

\section{Disclosure Statement}

M.S. has a patent for the EyeFlow ${ }^{\mathrm{TM}}$ technology. All other authors declare that they have no conflicts of interest. 


\section{References}

1 Lei H, Karniadakis GE: Quantifying the rheological and hemodynamic characteristics of sickle cell anemia. Biophys J 2012;102:185194.

2 Gladwin MT, Barst RJ, Gibbs JS, Hildesheim M, Sachdev V, Nouraie M, Hassell KL, Little JA, Schraufnagel DE, Krishnamurti L, Novelli E, Girgis RE, Morris CR, Berman Rosenzweig E, Badesch DB, Lanzkron S, Castro OL, Taylor JG 6th, Goldsmith JC, Kato GJ, Gordeuk VR, Machado RF; walk-PHaSST Investigators and Patients: Risk factors for death in 632 patients with sickle cell disease in the United States and United Kingdom. PLoS One 2014;9:e99489.

3 Scheinman JI: Sickle cell disease and the kidney. Nat Clin Pract Nephrol 2009;5:78-88.

4 Sharpe CC, Thein SL: Sickle cell nephropathy - a practical approach. Br J Haematol 2011;155:287-297.

5 Brenner BM, Lawler EV, Mackenzie HS: The hyperfiltration theory: a paradigm shift in nephrology. Kidney Int 1996;49:1774-1777.

6 Vazquez B, Shah B, Zhang X, Lash JP, Gordeuk VR, Saraf SL: Hyperfiltration is associated with the development of microalbuminuria in patients with sickle cell anemia. Am J Hematol 2014;89:1156-1157.

7 Aygun B, Mortier NA, Smeltzer MP, Hankins JS, Ware RE: Glomerular hyperfiltration and albuminuria in children with sickle cell anemia. Pediatr Nephrol 2011;26:12851290.

8 Barros FB, Lima CS, Santos AO, Mazo-Ruiz MF, Lima MC, Etchebehere EC, Costa FF, Saad ST, Camargo EE, Ramos CD: $51 \mathrm{Cr}$ EDTA measurements of the glomerular filtration rate in patients with sickle cell anaemia and minor renal damage. Nucl Med Commun 2006;27:959-962.

9 Guasch A, Navarrete J, Nass K, Zayas CF: Glomerular involvement in adults with sickle cell hemoglobinopathies: prevalence and clinical correlates of progressive renal failure. J Am Soc Nephrol 2006;17:2228-2235.

10 Ataga KI, Orringer EP: Renal abnormalities in sickle cell disease. Am J Hematol 2000;63: 205-211.

11 Guasch A, Cua M, Mitch WE: Early detection and the course of glomerular injury in patients with sickle cell anemia. Kidney Int 1996; 49:786-791.

12 Guasch A, Cua M, You W, Mitch WE: Sickle cell anemia causes a distinct pattern of glomerular dysfunction. Kidney Int 1997;51: 826-833.

13 Bakir AA, Hathiwala SC, Ainis H, Hryhorczuk DO, Rhee HL, Levy PS, Dunea G: Prognosis of the nephrotic syndrome in sickle glomerulopathy. A retrospective study. Am J Nephrol 1987;7:110-115.

14 McClellan AC, Luthi JC, Lynch JR, Soucie JM Kulkarni R, Guasch A, Huff ED, Gilbertson D, McClellan WM, DeBaun MR: High one year mortality in adults with sickle cell disease and end-stage renal disease. $\mathrm{Br} \mathrm{J}$ Haematol 2012;159:360-367.

15 Saraf SL, Zhang X, Kanias T, Lash JP, Molokie RE, Oza B, Lai C, Rowe JH, Gowhari M, Hassan J, Desimone J, Machado RF, Gladwin MT, Little JA, Gordeuk VR: Haemoglobinuria is associated with chronic kidney disease and its progression in patients with sickle cell anaemia. Br J Haematol 2014;164:729-739.

16 Gordeuk VR, Sachdev V, Taylor JG, Gladwin MT, Kato G, Castro OL: Relative systemic hypertension in patients with sickle cell disease is associated with risk of pulmonary hypertension and renal insufficiency. Am J Hematol 2008;83:15-18.

17 Hamideh D, Raj V, Harrington T, Li H, Margolles E, Amole F, Garcia-Buitrago M, Ruiz P, Zilleruelo G, Alvarez O: Albuminuria correlates with hemolysis and NAG and KIM-1 in patients with sickle cell anemia. Pediatr Nephrol 2014;29:1997-2003.

18 Wigfall DR, Ware RE, Burchinal MR, Kinney TR, Foreman JW: Prevalence and clinical correlates of glomerulopathy in children with sickle cell disease. J Pediatr 2000;136:749753.

19 Guasch A, Zayas CF, Eckman JR, Muralidharan K, Zhang W, Elsas LJ: Evidence that microdeletions in the alpha globin gene protect against the development of sickle cell glomerulopathy in humans. J Am Soc Nephrol 1999; 10:1014-1019.

20 Morris CR: Vascular risk assessment in patients with sickle cell disease. Haematologica 2011;96:1-5.

21 Kassim AA, DeBaun MR: Sickle cell disease, vasculopathy, and therapeutics. Annu Rev Med 2013;64:451-466.

22 Nath KA, Hebbel RP: Sickle cell disease: renal manifestations and mechanisms. Nat Rev Nephrol 2015;11:161-171.

23 Nath KA, Katusic ZS, Gladwin MT: The perfusion paradox and vascular instability in sickle cell disease. Microcirculation 2004;11: 179-193.

24 Serjeant GR, Serjeant BE, Condon PI: The conjunctival sign in sickle cell anemia. A relationship with irreversibly sickled cells. JAMA 1972;219:1428-1431.

25 Cheung AT, Harmatz P, Wun T, Chen PC, Larkin EC, Adams RJ, Vichinsky EP: Correlation of abnormal intracranial vessel velocity, measured by transcranial Doppler ultrasonography, with abnormal conjunctival vessel velocity, measured by computer-assisted intravital microscopy, in sickle cell disease. Blood 2001;97:3401-3404.

26 Kord Valeshabad A, Wanek J, Zelkha R, Lim JI, Camardo N, Gaynes B, Shahidi M: Conjunctival microvascular haemodynamics in sickle cell retinopathy. Acta Ophthalmol 2015;93:e275-e280

27 Cheung AT, Chen PC, Larkin EC, Duong PL, Ramanujam S, Tablin F, Wun T: Microvascular abnormalities in sickle cell disease: a com- puter-assisted intravital microscopy study. Blood 2002;99:3999-4005.

28 Lima CS, Rocha EM, Silva NM, Sonatti MF, Costa FF, Saad ST: Risk factors for conjunctival and retinal vessel alterations in sickle cell disease. Acta Ophthalmol Scand 2006;84: 234-241.

29 Paton D: The conjunctival sign of sickle-cell disease. Arch Ophthalmol 1961;66:90-94.

30 Wanek J, Gaynes B, Lim JI, Molokie R, Shahidi M: Human bulbar conjunctival hemodynamics in hemoglobin SS and SC disease. Am J Hematol 2013;88:661-664.

31 Bailie GR, Uhlig K, Levey AS: Clinical practice guidelines in nephrology: evaluation, classification, and stratification of chronic kidney disease. Pharmacotherapy 2005;25:491-502.

32 Chow CC, Genead MA, Anastasakis A, Chau FY, Fishman GA, Lim JI: Structural and functional correlation in sickle cell retinopathy using spectral-domain optical coherence tomography and scanning laser ophthalmoscope microperimetry. Am J Ophthalmol 2011;152:704-711.e2.

33 Chow CC, Shah RJ, Lim JI, Chau FY, Hallak JA, Vajaranant TS: Peripapillary retinal nerve fiber layer thickness in sickle-cell hemoglobinopathies using spectral-domain optical coherence tomography. Am J Ophthalmol 2013;155:456-464.e2.

34 Kidd JL, Azimi M, Lubin B, Vichinsky E, Hoppe C: Application of an expanded multiplex genotyping assay for the simultaneous detection of hemoglobin constant spring and common deletional alpha-thalassemia mutations. Int J Lab Hematol 2010;32:373-380.

35 Levey AS, Stevens LA, Schmid CH, Zhang YL, Castro AF 3rd, Feldman HI, Kusek JW, Eggers P, Van Lente F, Greene T, Coresh J; CKDEPI (Chronic Kidney Disease Epidemiology Collaboration): A new equation to estimate glomerular filtration rate. Ann Intern Med 2009; 150:604-612.

36 Arlet JB, Ribeil JA, Chatellier G, Eladari D, De Seigneux S, Souberbielle JC, Friedlander G, de Montalembert M, Pouchot J, Prié D, Courbebaisse M: Determination of the best method to estimate glomerular filtration rate from serum creatinine in adult patients with sickle cell disease: a prospective observational cohort study. BMC Nephrol 2012;13:83.

37 Shahidi M, Wanek J, Gaynes B, Wu T: Quantitative assessment of conjunctival microvascular circulation of the human eye. Microvasc Res 2010;79:109-113.

38 Gaynes B, Teng PY, Wanek J, Shahidi M: Feasibility of conjunctival hemodynamic measurements in rabbits: reproducibility, validity, and response to acute hypotension. Microcirculation 2012;19:521-529.

39 Kord Valeshabad A, Wanek J, Mukarram F, Zelkha R, Testai FD, Shahidi M: Feasibility of assessment of conjunctival microvascular hemodynamics in unilateral ischemic stroke. Microvasc Res 2015;100:4-8. 
40 Koutsiaris AG, Tachmitzi SV, Batis N, Kotoula MG, Karabatsas CH, Tsironi E, Chatzoulis DZ: Volume flow and wall shear stress quantification in the human conjunctival capillaries and post-capillary venules in vivo. Biorheology 2007;44:375-386.

41 Koutsiaris AG, Tachmitzi SV, Papavasileiou P, Batis N, Kotoula MG, Giannoukas AD, Tsironi E: Blood velocity pulse quantification in the human conjunctival pre-capillary arterioles. Microvasc Res 2010;80:202-208.

42 Field JJ, Knight-Perry JE, Debaun MR: Acute pain in children and adults with sickle cell disease: management in the absence of evidencebased guidelines. Curr Opin Hematol 2009; 16:173-178.

43 Denenberg BS, Criner G, Jones R, Spann JF: Cardiac function in sickle cell anemia. Am J Cardiol 1983;51:1674-1678.
44 Leight L, Snider TH, Clifford GO, Hellems HK: Hemodynamic studies in sickle cell anemia. Circulation 1954;10:653-662.

45 Singer M, Boghossian S, Bevan DH, Bennett ED: Hemodynamic changes during sickle cell crisis. Am J Cardiol 1989;64:1211-1213.

46 Gladwin MT, Schechter AN, Ognibene FP, Coles WA, Reiter CD, Schenke WH, Csako G, Waclawiw MA, Panza JA, Cannon RO 3rd: Divergent nitric oxide bioavailability in men and women with sickle cell disease. Circulation 2003;107:271-278.

47 Tharaux PL, Girot R, Kanfer A, Dussaule JC, Gaitz JP, Tribout L, Baudot N, Vayssairat M: Cutaneous microvascular blood flow and reactivity in patients with homozygous sickle cell anaemia. Eur J Haematol 2002;68:327-331.

48 Hatch FE Jr, Azar SH, Ainsworth TE, Nardo JM, Culbertson JW: Renal circulatory studies in young adults with sickle cell anemia. J Lab Clin Med 1970;76:632-640.

49 Day TG, Drasar ER, Fulford T, Sharpe CC, Thein SL: Association between hemolysis and albuminuria in adults with sickle cell anemia. Haematologica 2012;97:201-205.

50 Koutsiaris AG: Correlation of axial blood velocity to venular and arteriolar diameter in the human eye in vivo. Clin Hemorheol Microcirc 2014, Epub ahead of print.

51 Cockcroft DW, Gault MH: Prediction of creatinine clearance from serum creatinine. Nephron 1976;16:31-41.

52 Levey AS, Bosch JP, Lewis JB, Greene T, Rogers N, Roth D: A more accurate method to estimate glomerular filtration rate from serum creatinine: a new prediction equation. Modification of Diet in Renal Disease Study Group. Ann Intern Med 1999;130:461-470. 